\title{
Junction Device
}

National Cancer Institute

\section{Source}

National Cancer Institute. Junction Device. NCI Thesaurus. Code C50017.

A device designed to join two or more things. 